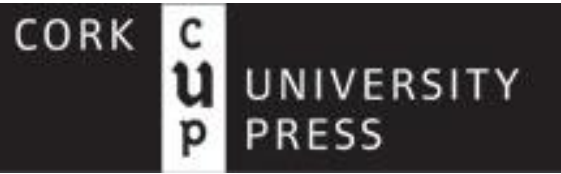

Post-Colonial Theory and Kiberd's 'Ireland' Author(s): Colin Graham

Source: The Irish Review (Cork), No. 19 (Spring - Summer, 1996), pp. 62-67

Published by: Cork University Press

Stable URL: https://www.jstor.org/stable/29735812

Accessed: 11-05-2020 11:54 UTC

JSTOR is a not-for-profit service that helps scholars, researchers, and students discover, use, and build upon a wide range of content in a trusted digital archive. We use information technology and tools to increase productivity and facilitate new forms of scholarship. For more information about JSTOR, please contact support@jstor.org.

Your use of the JSTOR archive indicates your acceptance of the Terms \& Conditions of Use, available at https://about.jstor.org/terms

Cork University Press is collaborating with JSTOR to digitize, preserve and extend access to The Irish Review (Cork) 


\section{Post-Colonial Theory and Kiberd's 'Ireland'}

\section{COLIN GRAHAM}

Declan Kiberd's Inventing Ireland ${ }^{1}$ represents a potentially new phenomenon in Irish literary criticism, since this is a text written with a consciousness of an audience beyond the academic. Explaining itself to what it implicitly figures as an interested but seemingly largely uninitiated readership, this book says things about Irish literature and cultural politics which will be extremely influential for their provenance as well as their substance. It is hardly surprising, then, that criticisms of Inventing Ireland have focused on its omissions. Inventing Ireland reads (perhaps inadvertently) like a literary history, the setting out of a canon - in moving from Wilde, Shaw and Somerville and Ross to the 1990s Inventing Ireland is opinionated, forceful in its arguments, and partisan in its readings. Because of its approach and breadth, Inventing Ireland, could be seen to bridge a gap in Irish culture between academic and public discourse while employing 'new' parlances derived from post-colonialism. In this, surely intentionally, it is close to Said's Culture $\mathcal{E}$ Imperialism, which translates aspects of post-colonial theory into a similar sort of book.

It is the use of post-colonial theory which is most central to the project of Inventing Ireland; this is a book which could not only represent a substantial attempt to use the post-colonial as a category for Irish literary criticism, but which could simultaneously undertake that task in a domain which pushes beyond the confines of institutional criticism in the way that post-colonial criticism often seems to demand. Inventing Ireland, at least in its opening, has the appearance of being the natural inheritor of the territory set out in David Lloyd's Anomalous States. If this were the case, then Inventing Ireland would be an even more extraordinary book than it is; but, while it is replete with scholarliness and intellectual liveliness, Inventing Ireland offers no extension of the post-colonial in Irish criticism - if anything it might be a regression in these terms, since it pulls the post-colonial into a rendition of Irish criticism which is primarily justified, rather than altered, by post-colonial theory.

The centrality of the post-colonial and a simultaneous disavowal of its usefulness is set out explicitly in Kiberd's 'Introduction' in which he says: 'My belief is that the introduction of the Irish case to the debate will complicate, extend and in some cases expose the limits of current 
models of post-coloniality' (p. 5). This is the most promising metacritical remark in the book: certainly the Irish case should alter post-colonial theory - but the theory must also be allowed to alter understandings of Irish culture, a possibility Kiberd seems unable to fully countenance. To assume only the possibility of a relationship in which Ireland adjusts post-coloniality is to assume failings in the conceptualisation of the post-colonial (which is presumably what Kiberd intends) and an innate ability in Irishness to lead the way in understanding colonial relations (and Kiberd continues this assumption in all sorts of often throwaway ideas throughout the book - his uncritical views of Irish missionaries and his hagiographical asides on Bob Geldof are more noticeable examples). There is a double tyranny in Kiberd's book: the sanctity of literature over theory and the residual but nevertheless evident sanctity of Irishness over non-Irishness (and this is not a criticism which can be levelled at the book lightly, since the bias emerges substantially in places). Both veil the possibilities of postcolonialism and at times disable the critical impact of what Kiberd says. This double-bind is exemplified when Kiberd explains (just before the sentence quoted above): '... I have refrained from attempts to "recolonise" Irish cultural studies in the name of any fashionable literary theory, preferring to allow my chosen texts to define their own terms of discussion' (p. 5). The notion that post-colonial theory (or theory per se) 'recolonises' may appeal to some readers; however, it seems incongruous in a text which then purports to employ post-colonial analogies consistently - and to me it represents the very worst kind of insularity in Irish criticism (bizarrely at odds with the pluralisms Kiberd discusses elsewhere) though not with his one-way, avuncular view of Ireland in post-colonialism. The mention of 'Irish cultural studies' here, incidentally, is as peculiar since it implies either a prioritisation of theory (a process which is here being rejected) or a deconstruction of the notion of 'high' art (a process which Inventing Ireland seems intent on reversing, if anything).

So how is post-colonial theory used in Inventing Ireland? It is immediately noticeable on reading Inventing Ireland that it has a particular vision of what post-colonial theory is. Its notion of what is 'recent' in the area is largely made up of references to Frantz Fanon (particularly The Wretched of the Earth published in 1961) and Albert Memmi (The Colonizer and the Colonized written in 1957). These are vital texts in the critical history of post-colonial theory, but they are hardly recent. Kiberd does use Said (or at least an allusion to Orientalism, published in 1978) and Gauri Viswanathan once (though Viswanathan's Masks of Conquest, not referred to, would actually refute some of the unique- 
ness, at least in chronological terms, which Kiberd sees in Irish resistance to colonialism). But truly 'recent' post-colonial theory (such as the work of Robert Young, Spivak, Bhabha and Abdul JanMohamed) does not figure substantially in Inventing Ireland - the impact of these theorisations is certainly never fully engaged with and the problem of using a theory while rejecting 'theory' persists throughout the text. The post-colonial theorist who Kiberd might find himself particularly in tune with, Aijaz Ahmed, is quoted, but again not substantially discussed.

Curiously this disinclination to engage with the ideas of other critics (beyond footnotes) also affects the points at which post-colonial and related theories have already crossed over into Irish literature. We might note the omission of Durcan, McGuckian or whichever writer we notice not to be here, but perhaps more relevant is that Inventing Ireland does not debate with David Lloyd, Clair Wills, Emer Nolan or David Cairns and Shaun Richards. An awareness of the potential audience for this book might explain these omissions. More likely they are the result of Kiberd's conviction of the priority of literature over criticism. Kiberd states that the Irish 'Renaissance' was 'a product of artists rather than academics', but this rather ignores the importance of the sort of critical act which Inventing Ireland itself will be, as well as setting up an overdetermined binary - one lesson post-colonial theory teaches us is that 'writing' and 'theory' are highly symbiotic. This prioritisation of the writer over the 'academic' also explains some of the omissions of post-colonial theorists already mentioned - their place is taken by post-colonial writers, most commonly Salman Rushdie (the post-colonial writer who, ironically, most explicitly integrates 'theory' into his writing) and to a lesser extent V.S. Naipaul. The comparisons here could get to the very heart of Irish post-colonialism, but Rushdie especially is most often used to confirm that the Irish case is like that described in Rushdie - and to use Rushdie in such sweeping and generalised ways tends to work against the nature of Rushdie's texts. One might also make the same criticism of omissions in this process: if Rushdie and Naipaul why not Walcott, Dabydeen, Rhys or Kureishi?

One commonly held aspect of post-colonial theory which is certainly 'recent' is the idea that anti-colonial nationalism was in fact derived from colonial models and that in practice (that is, in forming post-colonial statehood) anti-colonial nationalism could only replicate the structures of the imperialism which preceded it. This is obviously an assumption of great importance in the Irish case and Kiberd shows in many places how the idea can and will be useful for understanding that period of the formation of the Irish state which is at the centre of 
his book. Inventing Ireland's greatest achievement is to show how these structures of nationhood embedded themselves in Irishness in dialogue with the imperial power, and for this reason Kiberd's discussions of Wilde, early Yeats and Lady Gregory are fascinating and important critiques. One danger of this assumption is that one can extrapolate from the idea that Irish nationalism is founded on the colonial model to blame that model, rather than its descendant, for the faults of Irish nationalism (especially after it becomes the ideological driving force of the State). The extent to which 'blame' need be apportioned is an almost unanswerable question; how far it is actually carried out by critics is always revealing. Kiberd is often provocative and stimulating in his use of this idea, but perhaps extends it too far in noting that it was the advice of a 'British-trained Department of Finance' which persuaded de Valera to adopt exclusionist economic policies.

In a similar way the notion of hybridity as a typical condition arising out of colonialism is employed very successfully in places by Kiberd. His emphasis, though, tends to be on a kind of 'internal' Anglo-Irish hybridity (hence his chapter 'Protholics and Cathestants') rather than on hybridity which is English-Irish (and which may have produced much more radical revisions than appear in Inventing Ireland). Hybridity informs his best readings of Yeats and Wilde and is hinted at in his writing on Bowen (though this chapter is disappointingly short). Hybridity as a theoretical construct may never be able to entirely account for the hyphen in 'Anglo-Irish', but Kiberd's readings certainly show the way such readings might tend; Yeats's appearance on both sides of the hyphen, while at times unexamined and thus incongruous in this text, is undoubtedly explicable in these terms (Synge is interestingly read by Kiberd as a much more stable cultural entity).

The crux of Inventing Ireland becomes an analysis (and wariness) of the 'inventing' process. Kiberd's concluding remarks are generous to the spirit rather than the practice of revisionism, in that they are antimyth-making; add this to his use of the post-colonial assumption of the derivative nature of nationalism and Inventing Ireland might be close to a stringent examination of the extent to which Ireland is necessarily 'invented'. However the possibility that the cultural expression of Irishness is self-referential is the point at which Kiberd pulls back - Inventing Ireland finds, frequently, an Ireland and an Irishness which are 'authentic' and inauthentic. According to Kiberd: 'The attempt to express an authentic set of feelings through a flawed medium runs like a leitmotif through Irish renaissance texts' (pp. 2989). Kiberd derives his terms from Lionel Trilling's explication of sin- 
cerity and authenticity, and these terms become vibrantly appropriate at this point in the text. However that identification of an attempt at authenticity in the Irish 'renaissance' is Kiberd's as much as Wilde's, Yeats's, Synge's or Joyce's. Kiberd allows that authenticity is difficult, both as a concept and as a cultural reality, and he usefully points to the fact that authenticity is primarily cultural in that it demands a specific 'expression' and 'style'. But there is, even in the passage quoted above, the notion that to achieve authenticity the 'flawed medium' of English will be inadequate. Irish authenticity will thus, if it is at all achievable, by default use the Irish language. Kiberd also implicitly recognises that authenticity, while it must be expressed in culture, will never be simply culture-specific. Just after he notes that Synge's plays are confirmed in their authenticity because they were "triumphantly "translated back" into Irish', Kiberd goes on to say: 'All great works of literature are so because in some way or another they surpass the usual potentials of their own tongue, reaching out to a universal lan-

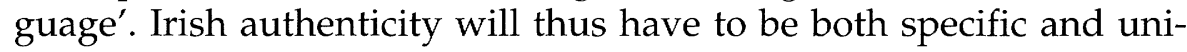
versal; this is truly Trilling speaking and is surely the greatest contradiction in this book. The notion of 'great' and universal literature, as many of the theorists underpinning Kiberd's work have acknowledged, has been a central ideology of English imperialism, Englishness, and Eurocentric liberalism for at least a century and a half. Gauri Viswanathan shows how in India 'great' literature was taught as an ideological tool; Kiberd himself discusses the Irish school curriculum. There is a vast critical debate seething underneath this term: Kiberd's approach may be explained by his prioritisation of literature over criticism, but to ignore such crucial debates and to use such a term uncritically is to annul so much of the careful reading which has gone before. Universality cannot be an unproblematic term, perhaps not even a usable term, in any discussion informed by postcolonialism; at the very least it needs some unpacking in its deployment.

Inventing Ireland will rightly be a vastly influential book in Irish literary criticism. It is wonderfully provocative, both on the level of specific readings and in its larger assumptions. Its often aphoristic style gives the book a sense of swagger and stylishness which is so often lacking in academic writing. How far Inventing Ireland furthers the theorisation of Irish literary criticism is open to debate - as a text it seems uncertain as to how far that theorisation should take place. Kiberd's book, full of important textual readings, piecing together a compelling narrative of the Irish nation in literature, may in the end be most influential for the ways in which it allows 'theory' and 'anti-theory' to 
clash. It has at the very least opened and confirmed gaps which later critics will no doubt seek to exploit, and in doing that it represents a major achievement in its field.

\section{NOTES:}

1. Declan Kiberd, Inventing Ireland: The Literature of the Modern Nation, (1995). 